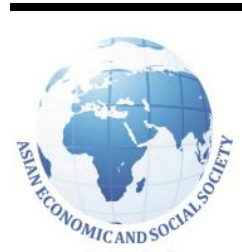

AESS

\section{Journal of Asian Business Strategy}

http://www.aessweb.com/journals/5006

DOI: $10.18488 /$ journal.1006/2015.5.11/1006.11.240.251

\title{
AN ASCERTAINMENT OF MULTI-SECTORIAL PROGRAMS FOR TRADE AND AID BETWEEN PAKISTAN AND SOUTH KOREA; CHALLENGES, OPPORTUNITIES AND WAY FORWARD
}

\author{
Mohsin Khan \\ Program Coordinator; Development Aid and Policy, Korea International Cooperation Agency, \\ Pakistan
}

\section{Article History:}

Received: 15 September 2015

Revised received: 22

October 2015

Accepted: 12 November 2015

Online available: 19

December 2015

\section{Keywords:}

Economic, sustainable development, bilateral, Korea

\begin{abstract}
The rapid and unprecedented social, economic growth, advancement in science and technology and improved governance in Republic of Korea embarked a new miracle in the history of the world. With an aim to explore and materialize these tremendous development experiences' the current study examine the existing trends, opportunities and potential sectors in Pakistan for sustainable economic development and suggested way forward to strengthen the cooperation between Pakistan and republic of Korea. The present study provide a descriptive analysis of both countries bilateral trade and ongoing cooperation and provide future strategy for utilizing certain developments which can revitalize Pakistan economy. The paper suggested that government and policy makers should consider the evolving nature of both countries and mutual interests through consultative meetings, visits and joint analysis. In sum, Pakistan and Korea can enjoy a mutually beneficial relationship as they enter a new era of friendship and Pakistan certainly will turn into another land of opportunity for Korea.
\end{abstract}

\section{INTRODUCTION}

\subsection{Pak-Korea relation; A historic connection}

Since its establishment in 1968, the Pak-Korea bilateral relations cover political, economic, trade, cultural, scientific, technological, military and educational fields that have been more strengthen over the time and periods. The trade turnover reached to its peak values of 1.341 billion US dollars. In May 2014, the Korean National Assembly Speaker and later the Prime Minister visit to Pakistan shows the growing economic potential of Pakistan for Korea. Both countries political clout is also growing after these successful visits. Likewise, Korean companies are now more interested to invest in Pakistan in the areas of chemical industry, Hydro and thermal power and infrastructure projects ${ }^{2}$. However, apart from these friendly relations, there has been little known to the both nations that PakKorea has a historic connection. The Monk Marananatha who is the first Budha to bring Buddhism to

Corresponding author's

Email address: mohsin_aup@yahoo.com

${ }^{2}$ Embassy of the Republic of Korea, Islamabad press release 
in Yeonggwang Korea in 38 AD traveled from Pakistan- Chota Lahore in Swabi District of Khyber Pukhtunkhwa. It had a great significance in Buddhist history and civilization in both countries (Iqbal, 2013) thus both cities had been declared twin cities after the visit of Mayer of Yeonggwang in 2013. Furthermore, when we study their development strategies and plans, we have to mention the supportive role of Pakistan toward Republic of Korea. The First Economic Development Plan designed by Dr. Mehboob-ul-Haq provided a road map to Korea that led economic and social prosperity in ROK.

\subsection{From ashes to dawn; Republic of Korea}

South Korea' a poor and desperate country successfully overcame the travails of World War-II, segregation of greater Korea peninsula in 1948 followed by the bloodiest War from 1950 to 1953-60. The country turned into a hell of social upheaval, poverty and destitute people with GNI per capita less than 58 US\$. But within a decade, a rapid industrialization and social transformation took place due to their radical and visionary leadership' the President General Park Chung-Hee (Hakeem, 2014). The miracles of Korea gave the developing countries a very solid imprint of implementation and execution of policy in its true spirit and letter. This commitment played a vital role in transformation of South Korea to raise its per capita income from 58 US dollars to 32,000 US\$ presently and it has emerged as a Donor from aid recipient country ${ }^{3}$. This journey of success and sustainable upward has several factors including human-oriented strategies and policies focused on motivating nation to work with diligence, cooperation and patriotically to work for rapid economic growth supported by true political will and commitment. These two major factor contributed to economic turnaround in the destiny of a hopeless and aid-dependent country to a world fastest economy in the world (Kim, 1991).

The prime objective of this paper is give a brief overview of Pak-Korea bilateral ties and to draw attention towards those potential sectors of Pakistan which can be interesting to the investors and donors to foster economic and social cooperation. The last section of the paper gave a brief recommendation to assist ROK to design multi-sector programs for sustainable development in Pakistan and other developing nations to attain Global Korea objectives.

\section{METHODOLOGY}

Since the research is of exploratory type therefore, most of the data were taken from secondary sources. The authors however, also collected primary data in term of aid, trade and human resource development from Korean Embassy and its donor Agency-Korea International Cooperation Agency (KOICA) in Pakistan. The data has been presented in tabulated and figures using Simple Statistics in next part of the paper.

\section{THE SOCIO-ECONOMIC PERSPECTIVE OF PAKISTAN}

Pakistan economy paid cost of war against terrorism, which escalated up to $\$ 90$ billion to $\$ 100$ billion, as well as it is confronting at both internal and external fronts. It economic growth remain on average of 2.9 percent. Since, last one decade and particularly during fiscal year 2013-14, several factor played a drastic role in reducing the growth rate including energy shortage, low capacity public enterprises, government negligence and menace of terrorism hemorrhaged the whole economy. Although, there was a trajectory increase in growth of more than 6 percent, but energy shortfall wiped out 2 percent of our Gross Domestic Product (GDP) and its major sectors including services, agriculture and manufacturing performance remained lower to its capacities.

The current national account has a deficit of 1.4 billion US dollar while the foreign reserves (liquid) have declined to 11.5 billion US Dollars in fiscal year 2012-13. Similarly, the review at national level from both large and small tax payer remained lethargic that resulted government to borrow from State Bank in order to support fiscal deficit (4.6 percent in 2013-14 as compared to 2012-13 6.4 percent of

${ }^{3}$ Hakeem (2013) The Korean Connection. The News on Sunday: Islamabad 
GDP $)^{4}$. However, the new government directed the ministries to displeasure over the pathetic macroeconomic performance as well as controlling energy shortfall and terrorism through national energy and counter-terrorism action plan during the outgoing fiscal year. Simultaneously, the ministry of finance took immediate steps to fix prevailing economic chaos in the country. The overall performer of national growth and economy is being summaries as follow:

- The per capita income increased from 1380 US\$ to 1512 US\$ in 2014-15 which shows growth of $9.25 \%$. Likewise, the Inflation rate showed a greater declined due to less price of crude oil in International market and it was recorded at $4.8 \%$ in 2014-15 against 8.7 percent in 2013-14.

- Since the energy crises affected catastrophically Pakistan's GDP, but in year 2014-15 it was estimated as $4.24 \%$ as compared to $4.03 \%$ and 3.6\%year 2013-14 and 2013-14 respectively. This shows growing trend in GDP of the country due to better performance of its various sectors. In year 2013-14, there was a major dip of gas and electricity production with a negative growth of $-3.2 \%$. However, this sector was recorded a sharp increase of $1.9 \%$ with overall contribution of $1.7 \%$ to current GDP in 2014-15. The agriculture sector showed a growth of $2.9 \%$ (last year $2.7 \%$ ), industries at $3.6 \%$ (last year $4.5 \%$ ) while service sector growth was estimated at $5.2 \%$ (last year $4.4 \%$ ).

- After successful negotiations and barging with International Monetary Fund (IMF), Asian Development and World Bank, Pakistan has been declared loan recipient. The World Bank also recommended the lending that was rendered in 2009. There has been substantial growth of Exports (4.2\%) with increment of 20147 million US Dollars from 19329 million US dollars in last year. The Imports, however showed negative growth $-1.02 \%$ with 36.66 billion US Dollars against37.1 billion US Dollars in year 2013-14.

- Services sector growth in contribution of wholesale and retails (at growth of $2.52 \%$ ) was estimated as $3.71 \%$ while transportation, communication and storage stood at $3.4 \%$, Insurance and Finance at $6.64 \%$, services of houses at $3.99 \%$ while public and private sector at $5.60 \%$ $3.99 \%$ respectively ${ }^{5}$.

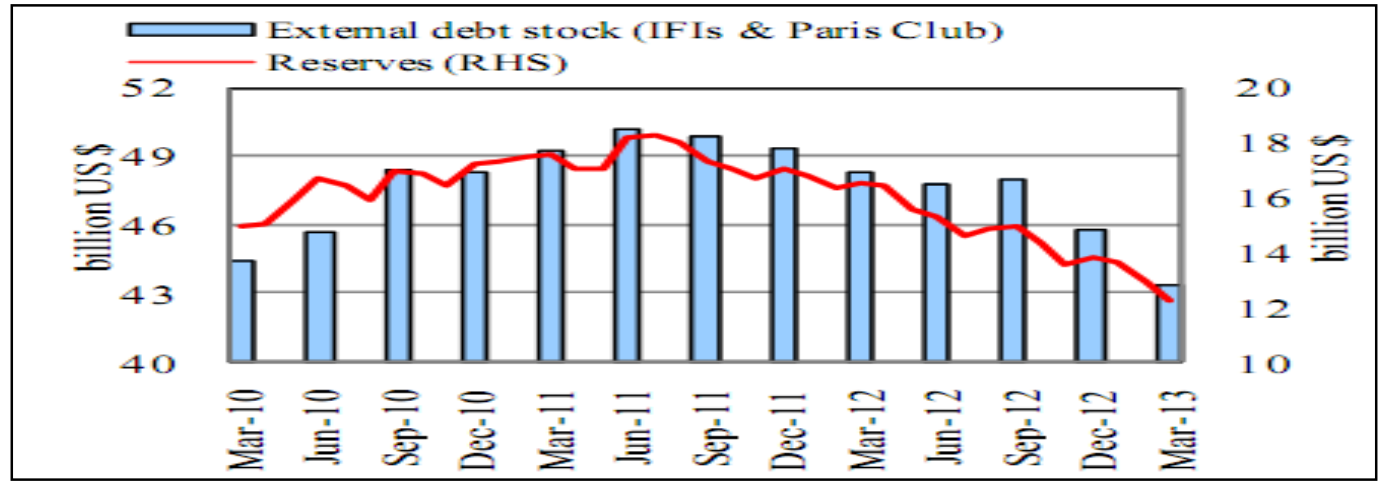

Figure 1: Foreign reserve and external debt stock (Liquid FR) state bank of Pakistan

- The Capital Stock market including stock exchange also excel as compared to other global markets including China, India and USA. The Karachi Stock Exchange (KSE)-100 index crossed 19000 level to 22000 marks at the end of General Elections and new government as compared to last year 13801.4.This trend was followed at increased by $57 \%$ due to substantial foreign investor interest and investment, low inflation, law and order situation, solid implementation rules of Capital Gain Taxes, Abolishing cooperative in country stock exchanges and decline in discount rate by State bank to $9.5 \%$. The ongoing fiscal year showed better performance in foreign direct investment with 17.9 percent increase as compared to other countries. The Sectorial increased was recorded at $17.9 \%$ as compared to $2012-13$ as shown in Table 1.

\footnotetext{
${ }^{4}$ Economic Survey of Pakistan. 2013-14: Islamabad

${ }^{5}$ Economic Survey of Pakistan, 2013-14, 2014-15: Islamabad
} 
Commodity Producing Sector (CPS) performance was outstanding as its growth was 3.4\% as compared to 3.1\% in year 2012-13.The Pakistan's agriculture system has food items and raw materials use in industries and it accounts for 21.4 percent of total GDP providing employment opportunities to more than 45 percent of population. The agriculture sector performance remained lower due to harsh weather, floods and energy shortfall that resulted low production of Rice and Cotton. Therefore, the agricultural growth was computed as 3.3 percent comparing last year of 3.5 percent (Economic Survey of Pakistan, 2014$)^{6}$.

Table 1: Analysis of FDI flow by major sector in Pakistan (Million US Dollar)

\begin{tabular}{|c|c|c|c|c|c|c|c|c|c|c|c|c|c|}
\hline Sectors/Year & $\begin{array}{c}\text { Oil } \\
\& \\
\text { Gas }\end{array}$ & Commerce & Textiles & Trade & $\begin{array}{l}\text { Building \& } \\
\text { Construction }\end{array}$ & Power & Chemical & Transport & Communication & Other & $\begin{array}{l}\text { Total } \\
\text { +Pvt. }\end{array}$ & Privatization Earnings & $\begin{array}{c}\text { FDI minus } \\
\text { Pvt. } \\
\text { Incomes }\end{array}$ \\
\hline $2007-2008$ & 634.8 & $1,864.90$ & 30.1 & 175.9 & 89 & 70.3 & 79.3 & 74.2 & $1,626.80$ & 764.5 & $5,409.80$ & 133.2 & $5,276.60$ \\
\hline 2008-2009 & 0 & 707.4 & 36.9 & 166.6 & 93.4 & 130.6 & 74.3 & 93.2 & 879.1 & 763.4 & $3,719.90$ & 0 & $3,719.90$ \\
\hline $2009-2010$ & 0.6 & 163 & 27.8 & 117 & 101.6 & -120.6 & 112.1 & 132 & 291 & 586.3 & $2,150.80$ & 0 & $2,150.80$ \\
\hline 2010-2011 & 0.2 & 310.1 & $25.3 / \mathrm{td}>$ & 53 & 61.1 & 155.8 & 30.5 & 104.6 & -34.1 & 416.3 & $1,634.80$ & 0 & $1,634.80$ \\
\hline 2011-2012 & 0.4 & 64.4 & 29.8 & 25.3 & 72.1 & -84.9 & 96.3 & 18.7 & -312.6 & 282.6 & 820.7 & 0 & 820.7 \\
\hline 2013-2014 & 296.2 & 102.8 & -1.1 & -8.5 & 14 & 21.6 & 58.4 & -5.2 & -121.2 & 81.8 & 606.3 & 0 & 606.3 \\
\hline
\end{tabular}

Economic Survey of Pakistan 2013-14

\footnotetext{
${ }^{6}$ Pakistan Bureau of Statistics, Agriculture Statistics 2013-14: Islamabad
} 


\subsection{Social indicators of Pakistan}

Pakistan has a fast growing population with 191 million people in 2015 . Being the $6^{\text {th }}$ most populated country of the world' around 58 million are multidimensional poor. The rural population below poverty line (1.25 US\$) is 46 percent and urban 18 percent. The single hospital per 1127 person/doctor and single hospital bed for 1786 patients is available according to national statistics. The National Nutrition Survey by Aga Khan University Division of Women and Child Health, the Pakistan Ministry of Health and UNICEF on overall nutritional status of target groups, including preschool children (six to 59 months), school-aged children (six to 11-years-old), women of childbearing age (15 to 49 years old) and elderly persons (50 years and greater) ${ }^{7}$ revealed a very miserable situation of meal and under-nutrition. The report indicates that 58 percent of households were food-insecure nationally while Sindh was the most food-insecure province, followed by Balochistan. A whopping 72 percent of families in Sindh and 63.5 percent in Balochistan faced food insecurity as per the results of this survey ${ }^{8}$. Likewise, the unemployment remained a central problem with 6 percent in 2011 and it has been decreased in rural areas to 4.7 percent from 4.8 in 2010 . The unemployment remained higher in urban area with increased to 8.8 percent. Pakistan's literacy rate is remained at 58 percent with higher ratio in urban than villages. Gender-based literacy showed a large variation between men $(80 \%)$ and women $(66 \%)$. Punjab and Sindh remained at higher literacy (60\%) while Khyber-Pukhtunkhwa and Balochistan showed 52 percent and 46 percent respectively (PSLM, 2012) ${ }^{9}$.

\section{FOREIGN AID: NEXUS TO SOCIO-ECONOMIC GROWTH AND DEVELOPMENT}

Since its inception in 1947, Pakistan is largely dependent upon Development aid from international communities. This aid has been used not only for bridging the gap between saving investment foreign exchange as well as social-economic and political governance. According to Javaid and Qayyum (2011), the external assistance has a major objective to stimulate economic development, stabilizing economy, improving infrastructure as well as supporting sub-sectors such as agriculture and manufacturing through new knowledge and techniques. They also identified the significant of foreign aid on strengthening social sector such as health, education, environment and democracy and governance systems. A good external aid support existence consumption of food and stabilize the economy in various shocks. However, Pakistan despite having greater external aid has still worse condition and is still aid dependent. This grim reality has provoked another idea to support aid for trade in developing countries and conditional cash program to enhance aid effectiveness ${ }^{10}$.

According to the State Bank Report 2012 quantifying each donor's share of gross Official Development Assistance (ODA) that flowed into Pakistan in 2011. Total gross disbursements amounted to $\$ 4.15$ billion (constant $2011 \$$ ). The United States was the largest contributor, constituting nearly a third of total ODA to Pakistan, and is followed by the World Bank's International Development Association (21 percent of total ODA), Japan (14 percent), the United Kingdom (8 percent), and the EU Institutions (4 percent) as shown in Table 2.

\footnotetext{
${ }^{7}$ Baloch (2011) Malnourished Nation. Daily Time March 24 ${ }^{\text {th }}, 2014$. (www.dailytimes.com.pk/opinion/28-Mar2014/malnourished-nation)

${ }^{8}$ National Nutrition Survey, 2011-12; Agha Khan University, UNICEF and Ministry of Health Pakistan

${ }^{9}$ Pakistan Social and Living Standard Me a s u re ment(PSLM) survey 2011-12, 2013-14 by Pakistan Bureau of Statistics, 2012-13, 2014-15: Islamabad

${ }^{10}$ Javaid and Qayyum (2011) Foreign Aid and Growth Nexus in Pakistan: The Role of Macroeconomic Policies. PIDE: Islamabad
} 
Table 2: Aid Flow to Pakistan (2011)

\begin{tabular}{lcc}
\hline Donors & Total Aid (in Million US\$) & Share of total aid (\%) \\
\hline United States & $1,276.26$ & $30 \%$ \\
IDA & 879.75 & $21 \%$ \\
Japan & 573.32 & $14 \%$ \\
Sum of other small donors & 394.00 & $9 \%$ \\
(<15 million each) & 334.01 & $8 \%$ \\
United Kingdome & 256.59 & $6 \%$ \\
EU Institutions & 157.96 & $4 \%$ \\
Germany & 94.44 & $2 \%$ \\
ADB special Funds & 87.49 & $2 \%$ \\
Canada & 74.34 & $2 \%$ \\
Australia & 71.34 & $2 \%$ \\
\hline United Arab Emirates & \\
\hline
\end{tabular}

Source: OECD Creditor Reporting System, Table DAC 2 a, accessed July 2013

There has been another emerging concept in Aid is "Aid for Trade "launched in 2005 in order to improve the effectiveness and sustainability of foreign assistance and to liberalized trade and global markets for developing nations. This initiative encourage developing and least developing countries in identifying objectives of trade in their economic development plan. It support the donors and international communities to identify trade objectives in these countries development plans assist in utilizing available resources for economic growth and poverty alleviation (OECD, 2010-11). Therefore, the donors will provide assistance after designing the programs for improving capacities of the developing country to expand their local resources and grow trade through access to markets globally under the international trade system ${ }^{11}$.

\subsection{The Korean aid and bilateral support}

The Republic of Korea through its grant aid and soft loan program assisted Pakistan's infrastructure, Energy, and also supported Trade to ensure regional stability supported with sustainable social and economic development. The Economic Development and Cooperation Fund (EDCF) aided Pakistan's development goals in the fields of transportation and communication, water resource development and energy and infrastructure. Meanwhile Korea International Cooperation AgencyKOICA) continually supporting Pakistan in Human resource and other prioritize sectors as shown in Table 3, 4 and Figure 2.

Table 3: The Project Supported by ROK through EDFC

\begin{tabular}{|c|c|c|c|c|}
\hline $\begin{array}{l}\text { S. } \\
\text { No }\end{array}$ & Sectors & Name of Project & $\begin{array}{l}\text { Amount } \\
\text { Tentative } \\
\text { (US\$ M) }\end{array}$ & STATUS \\
\hline 1 & \multirow{3}{*}{ Energy } & $\begin{array}{l}\text { National Transmission and Distribution } \\
\text { Corporation through Procuring Latest } \\
\text { Equipment For } 220 \mathrm{KV} \text { Grid Station in Lahore } \\
\text { (1997) }\end{array}$ & 20 & $\begin{array}{c}\text { DISBURSE } \\
\text { D }\end{array}$ \\
\hline 2 & & $\begin{array}{l}\text { GEPCO-7 Grid Stations In Gujranwala, } \\
\text { Pledged (2007) }\end{array}$ & 45 & OPEN \\
\hline 3 & & $\begin{array}{l}\text { Procurement Of Equipment For } 220 \text { KV Grid } \\
\text { Station, Lahore Supplementary Loan, Pledged } \\
\text { (2011) }\end{array}$ & 7.2 & OPEN \\
\hline 4 & $\begin{array}{l}\text { Infrastructure } \\
\text { (Road and } \\
\text { Transportation) }\end{array}$ & Malakand Tunnel Project, Pledged (2011) & 78 & OPEN \\
\hline 5 & Health and & Children Hospital, Sukkur, Under Serious & 46 & OPEN \\
\hline
\end{tabular}

${ }^{11}$ OECD (2011), Aid for Trade in LDCs: Starting to Show results, OECD/WTO 
TOTAL

$$
\text { Consideration Pledged (2012) }
$$

Source: Korean Embassy, Islamabad

196.2

Table 4: Grant in aid projects in Pakistan by KOICA

\begin{tabular}{ll}
\hline S. No & \multicolumn{1}{c}{ Projects Titles } \\
\hline 1 & $\begin{array}{l}\text { Pakistan-Korea Garment Technology Institute Phase-I, Karachi, (US\$ 2 M, 2011-13) } \\
\text { Pakistan-Korea National Capacity Building Institute (NCBI) for Water Quality } \\
\text { Management at PCRWR, Islamabad (US\$ 3 M, 2011 2013) }\end{array}$ \\
\hline 3 & $\begin{array}{l}\text { Safe Drinking Rural Water Supply Schemes in Mandi Bahauddin, Punjab, (US\$ 4 M, } \\
\text { 2011 2014) }\end{array}$ \\
\hline 4 & $\begin{array}{l}\text { Pakistan-Korea ICT Center of Excellence in CTTI Islamabad, (US\$ 5 M, } \\
\text { 2011 2013) }\end{array}$ \\
\hline 5 & $\begin{array}{l}\text { Pakistan-Korea Capacity Building Center for Agri and Livestock Technology, } \\
\text { Rawalpindi, (US\$ 3.5 M, 2012 2015) }\end{array}$ \\
Waste Water Treatment facility in Patoki, Kasur District, (US\$ 4 M, 2012 2014) \\
\hline 8 & $\begin{array}{l}\text { Pakistan-Korea Technical Textile Center in National Textile University-Faisalabad, } \\
\text { (US\$6.5 M, 2013-2016) }\end{array}$ \\
KOICA- JICA Joint Training program for the Crises Effected People of Malakand \\
Division, ( US \$ 0.6 M, completed)
\end{tabular}

Source: KOICA Pakistan Office, 2013-14

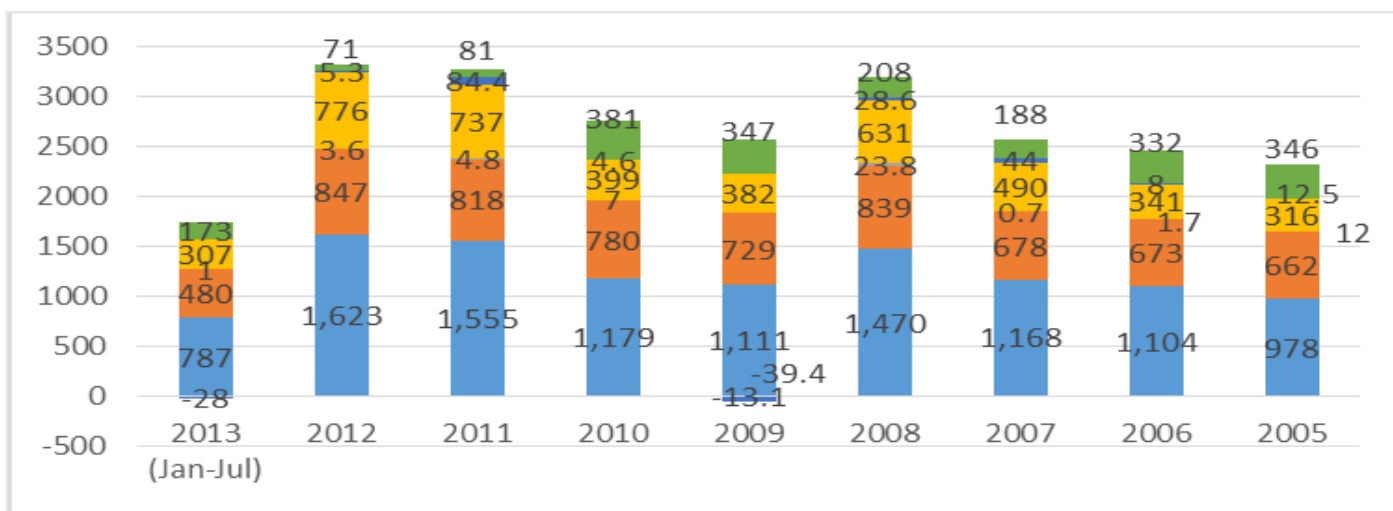

Figure 2: Overview of Bilateral Trade between Pakistan and South Korea 2005-2013

Source: Embassy of Republic of Korea in Pakistan

\section{ENHANCING BILATERAL TRADE AND FINDING OPPORTUNITIES}

The ruling party Pakistan Muslim League (PML-N) economic manifesto narrate some of very significant aspects to ensure economic revival in a peaceful environment. The serpent of terrorism and law and order situation is the main hurdle to materialize the task. However, there has been efforts to attract foreign investment particularity Korean in different sectors. Pakistan has also offered many incentives to the Korean investors (in the light of Vision East Policy) including setting up of a Special Economic Zone. Trade between Korea and Pakistan is 1.341 billion US dollars (see figure 2) but this bilateral trade is less than and exclude several sectors where both can invest. For 
instance, in textiles and clothing which share of 24 percent GDP, employing 38 percent of the population and have total share in export around 70 percent. It has several challenges including energy crises, lack of research and technology, poor quality and value-addition along with less competency (unskilled labor). Korea has unique experiences in this sector and can help Pakistan in this sector to resolve some of these issues through different programs and exchange of technology, skills and investment.

Since, the encouraging news is the grant of duty-free access to Pakistani exports-mostly textile and clothing to EU's 27 member countries under the GSP Plus scheme. It is likely to boost economic and investment opportunities in the country, if all Korean Investor play their role proactively. As Pakistan is a country of 180 million vibrant middle class people having an increasing purchasing power and possesses a huge reservoir of highly skilled and disciplined human resource. In addition, foreign exchange rate parity makes the local fabrication and manufacturing very attractive and competitive for exports. Therefore, Pakistan-Korea's economic partnership could prove equally beneficial to both sides provided the true potential is exploited to optimum level (Economic Survey of Pakistan 2013-14 and Trade Development Authority, Islamabad).

\subsection{Korea knowledge sharing and development experience exchange programs}

Korean government designed a Knowledge Sharing Program (KSP) in order to share its social, economic, technological and scientific advancement with other developing countries in 2004. It comprises of research, policies formulation through joint consultation, human resource development through training and capacity development to assist developing countries to achieve goals for socioeconomic uplift. This program neither intended to offer definitive recipes for a country of having a specific economic or social challenge, nor imposing Korean knowledge in the developing countries. But it aim to provide a practical and useful policy alternates based analyzing partner country challenges on similar cases and experience Korea was confronting earlier. In 2010, Pakistan was also included in KSP program and several public and private institutes from both countries such as Korean Development Institute and Planning Commission of Pakistan signed a memorandum of understanding to cooperate in different sectors to capitalize objectives of KSP. There is a dire need to revisit KSP and include Universities (public and private), Local Business companies, Youth Organization, Journalists (print and Electronic media), Non-governmental organization (NGOs) and Community based organization which can bring up a rapid social transformation.

\subsection{The Saemaul Undong-new village movement initiative for Pakistan's rural areas}

After the wrath of Korean War, the per capital income of Korea similar to African countries i.e. Ghana 58 US dollars. The wide spread poverty in the rural areas led the president Park to devise a new vision of rural innovation and social transformation through Saemaul Undong; New Village Movement Program-a people led initiative to revitalize rural infrastructure, build capacities of rural leader and strengthening rural economy. Within a decade, 1970, the whole Korean was changed with the materialistic and spiritual movement by the President Park. Pakistan where 65 percent of its population lives in villages and almost 70 percent of which are farmers' can learn from Korea's experiences $^{12}$. Pakistan which ranks in Multidimensional Poverty Index (MPI) with score of 0.264 after the Bangladesh and Nepal (0.292 and 0.217) in South Asian countries (UN World Development Report, 2013) more than 23 percent live in acute poverty. In the past, government of Pakistan has taken several steps to reduce rural poverty such as Village Agricultural and Industrial Development in 1953, Basic Democratic System (1963) and The Rural Works Program in 19631972), yet failure to implement these policies and program produce new problems for rural people. These programs were initiated to empower rural communities and generate local resource for better productivity and improved livelihood but due governance, corruption and non-political will, these projects failed and the situation is getting worse. Therefore in order to harness the benefits of New Village Movement, the present government and Korea should take immediate steps to improve the rural areas, address the widespread issues such as poverty, food insecurity, population growth,

\footnotetext{
${ }^{12}$ (World Bank, 2009). "Implementing Agriculture for Development: World Bank Group Agricultural Action Plan2010-1012,” July 2009, p.14.
} 
illiteracy, water and irrigation and poor infrastructure followed by "mental reforms" in masses using Pakistan greater potential in crops, livestock, Handicraft, small home based industries and fisheries have strong implication for SMU to be replicated in Pakistan.

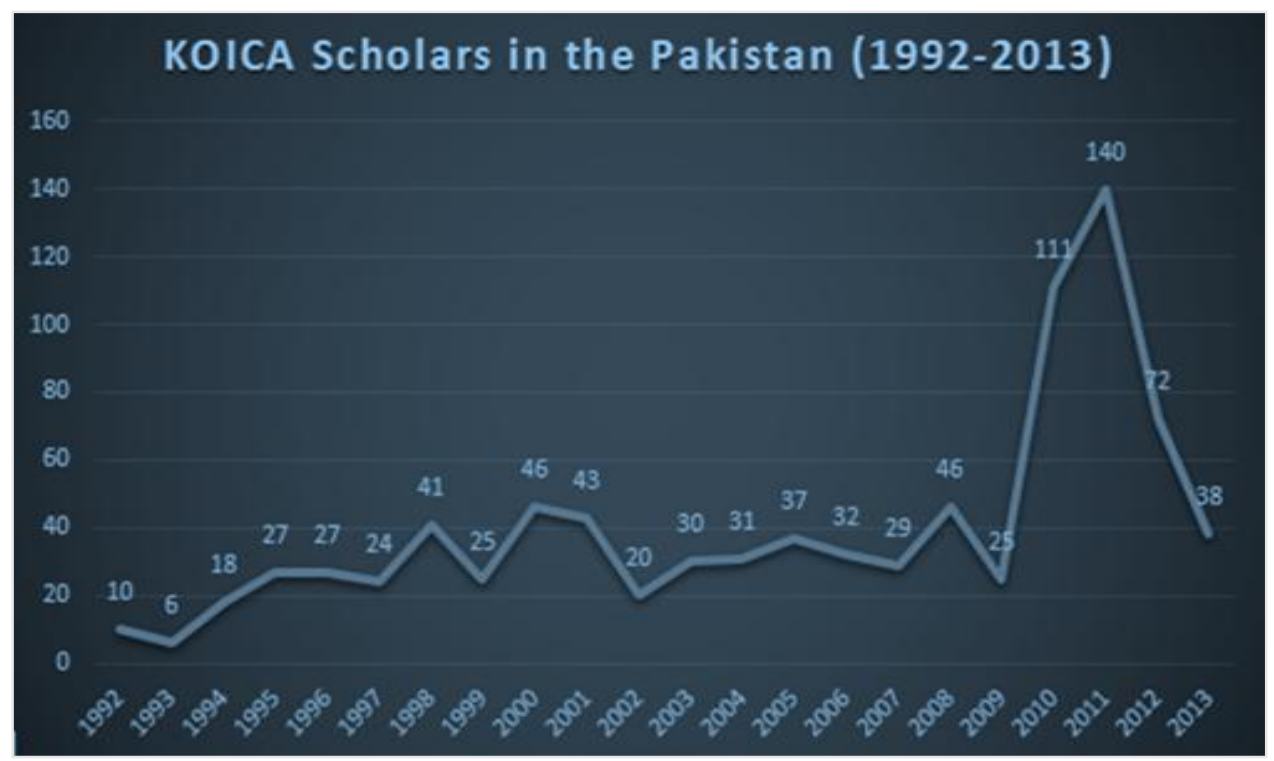

Figure 3: Technical cooperation, no. of trainee from Pakistan bureaucracy (1992-2013)

Source: Data Bank of KOICA Office in Pakistan, 1991-2013

\subsection{Higher education, science and technology and energy sector}

No doubt, a country which invest heavily in its education and particularly science and technology always succeed in sustainable economic development. Pakistan having a greater human resource potential, and utilizing its existing research facilities, need to acquire educational and technological competences from rest of develop countries such as Korea in order to maintain its life in the global marketplace. South Korea which excelled in its higher education, research, Science and Information technology can play a prominent role in developing this sector. Having 23 nuclear power plants which fulfill 38 percent of Korea's demand in electricity, can be a good source of knowledge for Pakistan to cope with energy crises. Since, several Korean companies are investing in different fields (IT, Electric and Electronics, Chemical and Steels, Building and Infrastructure, Road and Transportation and Energy), there is a dire need to build linkage between Korean research institutes such as Korea Institute of Science and Technology (KAIST), Korea Development Institute, other universities and Higher education commission along with companies and Multinational cooperation.

\subsection{Human centered program for capacity development}

The only way for sustainable aid effectiveness is to build the people and change their attitude via capacity building programs. So far, Korea International Cooperation Agency (KOICA) has sponsored more than 1000 officials to Korea for long and short term trainings (shown in graph). Those trainee formulated a KOICA Alumni Association of Pakistan (KAAP) with regular events to promote culture as well impart their knowledge not only within their organizations but also to the society at large. These members, in the spirit of volunteerism, also implements developmental and welfare activities in rural and other communities. In the meantime, there is a dire need to consider the gross root organizations and university and faculty members in this area. These trainings are for not only project based but to governmental official to learn about Korea advancement in Science and Technology and other fields. In year 2014, 17 master degree programs and 6-9 short term trainings programs are designed for Pakistan. HRD Korea is also playing vital role in bringing people to people contact, increasing in foreign remittance to Pakistan and skill labor for Korea 
respectively. A large of Pakistani including workers, students and businessmen are staying in Korea. According to Overseas Employment cooperation, 4700 worker, 510 academic professional and more than ten thousand Pakistanis are staying in Korea since 2012.

\subsection{Joint exploration for mineral, gems and jewels}

Pakistan's mining sector accounts 13.3 percent of total GDP and employs 14 percent of labor in Pakistan. It has witnessed a growth of 3.8 percent in 2014 as compared to 1.65 in last year ${ }^{13}$ and has a greater potential for export if proper exploration and polices are followed. Pakistan Mineral Development Corporation has several ventures for 1) exploration of base metals and gold, coal, 2) thermal power plants through coals and 3) ultra-refined salts in Balochistan, Punjab, KP and Northern areas. The government has allocated 1,400 concessions to mining which contributed 2.4 million US dollar to Gross national products (GNP). Pakistan's premium coal, gold, copper, zinc and silver reservoirs which are estimated to be world $5^{\text {th }}$ largest deposit in the World are in Rekodek Balochistan. The estimated value of these gold mines are 260 billion US dollars. Dr. Samar Mubarak mend Chief of Mineral Resource Pakistan, says that the worth of these mines are more than 1.2 trillion US dollars ${ }^{14}$. So far only some Chinese and European companies are doing exploration at a very minimal charges to Pakistan. The Republic of Korea can take a greater benefit in future since Pakistan has a good edge for the gems and jewelry sector, as we have huge resource of raw gemstone as well as the additional factor of low cost of production, talented, energetic, and hardworking artisans are the significant promising features for investment. The value addition at source by gem processing will be in the interest investors as the raw material will be readily available and processing can be made comparatively at lower cost.

\subsection{Tourism and traveling; New dimension for economic growth}

Tourism and traveling is one of the most economical activity in the world and it play a significant role in not only generating revenue but also closing people with each other. According to World Travel and Tourism Council report 2014, state that Pakistan tourism sector alone contributed 6.9 percent of total GDP to Pakistan and provided 6.7 percent employment to people. In year 2014, this sector alone provided 17.2 billion US dollars contribution to GDP of Pakistan despite the security threats. On other hand, Korea has contributed 81 billion US dollars with 5.8 percent contribution to its GDP by this sector ${ }^{15}$. Keeping the historic connection, splendorous beauties ranging from cool peaks of Karakorum to the historic civilization of Mohenjo-Daro and enchanting Islands and Enchanting Urban cities and temples in Pakistan and Korea respectively have several opportunities in this sector and can bring prosperity among both countries.

\section{CONCLUSION}

Although it is well documented that development strategies are designed according to country's specific social-cultural and economic resources and policies of another countries cannot to be applied directly. However, developing countries, including Pakistan, can feasibly replicate Seoul's development strategy to achieve pragmatic results for social and economic development since it is Pakistan's own plan that was successfully replicated and implemented by the Korean government. During an International seminar on Economic Development and Saemaul Undong (November, 2013) at PMAS-Arid Agriculture University Rawalpindi, the South Korean delegate and high officials with open heart proclaimed that they have adopted Pakistan's five year plan. But the question is why we are still not able to utilize its full potential. According to those Korean experts the development plan alone cannot change the economic situation therefore, a very holistic policy which incorporate export and industries for demand driven changes. Korean aid and trade can assist Pakistan if there is unwavering political support, high spirit of the entrepreneurs to penetrate the global market with quality orientated products, implementing policies in its letter and spirit and providing global trading environment to investors along with enhancing domestic investment and

\footnotetext{
${ }^{13}$ Economic Survey of Pakistan, Islamabad 2014-15

${ }^{14}$ Pakistan Board of Investment; Islamabad, 2013

${ }^{15}$ World Travel and Tourism Economic Impact, Pakistan and South Korea, 2015
} 
$\operatorname{saving}^{16}$

The current economic-political scenario, Pakistan offers several opportunities in mentioned sectors, but the prospects for large-scale developmental projects and business opportunities remain subject to progress improving law and order and power supply. However, the current government plans to build an Economic corridor linking Kashgar in the People's Republic of China to the Pakistani port of Gwadar, and this megaproject could significantly boost private investment and growth in the coming years. These developments should be capitalized by both countries as well as Pakistan should revisit its policies on investment, security, social sectors (population, education and health) along with building agricultural economy in the light of Korean's expertise. These opportunities can be explored through consultative meetings, visits and joint analysis.

Furthermore, in order to address the poverty and concern of low income groups, government should have pursued policies in the social sectors to improve the standard of living of the common man by improving literacy rate, improving the status of women, curtailing population growth and providing primary health care to the poor. The Korea export oriented-outward policies and conducive environment for the business along with focused on human development made miracle on hand river. Therefore, keeping in view the potential of Pakistan and experiences of Korea, the study suggested that Republic of Korea and its aid agency should consider Pakistan's greater potential investment and trade and should focus on building human capacities. The Korean aid should be increases keeping in view the dynamic nature of socio-economic issues. In sum, Pakistan and Korea can enjoy a mutually beneficial relationship as they enter a new era of friendship and Pakistan certainly will turn into another land of opportunity for Korea.

Funding: This study received no specific financial support.

Competing Interests: The authors declare that they have no conflict of interests.

Contributors/Acknowledgement: All authors participated equally in designing and estimation of current research.

Views and opinions expressed in this study are the views and opinions of the authors, Journal of Asian

Business Strategy shall not be responsible or answerable for any loss, damage or liability etc. caused in relation to/arising out of the use of the content.

\section{References}

Baloch, S. (2011). Malnourished nation. Daily Time, Mar $28^{\text {th }}, 2014$; Islamabad Online available at http://www.dailytimes.com.pk/opinion/28-Mar-2014/malnourished-nation.

Center for Global Development (2013). Aid to Pakistan by the Numbers. Online available at http://www.cgdev.org/page/aid-pakistan-numbers.

Embassy of the Republic of Korea (2013-14). EDCF Program Disbursement to Pakistan. Islamabad. Online available at http://www.koreanembassy-pakistan.org/partnership/edcf.do.

Federal Bureau of Statistics (2011-12 and 2012-13). Islamabad, Pakistan Social and Living Standard Measurement (PSLM) survey.

Hakeem, F. (2013). The Korean connection. The News on Sunday, February 23 ${ }^{\text {rd }}$, 2014: Islamabad Online available at http://tns.thenews.com.pk/south-korea-developmentstrategy/\#.VIUuYHYrLIU.

Iqbal, A. (2013). Swabi has a sister city in S. Korea. Published in Dawn News Paper April, $15^{\text {th }}$, 2013. Online available at http://www.dawn.com/news/802621/swabi-has-a-sister-city-in-skorea.

Javaid, M., \& Qayyum, A. (2011). Foreign aid and growth nexus in Pakistan: The role of macroeconomic policies. Pakistan Institute of Development Economics, Working paper 2011: 21, Islamabad.

Kim, K. S. (1991). The Korean miracle (1962-1980) revisited: Myths and realities in strategy and development. Working Paper 166 - November 1991.

${ }^{16}$ Hakeem (2013). The Korean Connection. The News on Sunday: Islamabad 
Economic Survey of Pakistan (2014-15). Ministry of finance, Government of Islamic republic of Pakistan, Islamabad, Report.

Economic Survey of Pakistan (2013-14). Ministry of finance, Government of Islamic republic of Pakistan, Islamabad, Report.

Economic Survey of Pakistan (2012-13). Ministry of finance, Government of Islamic republic of Pakistan, Islamabad, Report.

Federal Bureau of Statistics (2012-13). Ministry of finance, Government of Islamic republic of Pakistan, Islamabad, Annual Statistical Report.

National Nutrition Survey (2011-12). Agha khan university, UNICEF and Ministry of Health Pakistan.

Organization for Economic Cooperation and Development (2011). Aid for Trade in LDCs: Starting to Show results, OECD/WTO. Geneva Switzerland online available at https://www.wto.org/english/res_e/booksp.../aid4tradeinaction13_e.pdf.

Pakistan Board of Investment (2013). Islamabad, online available at www.boi.gov.pk

World Bank, (2009). Implementing Agriculture for Development: World Bank Group Agricultural Action Plan 2010-1012. p. 14.

World Travel and Tourism Economic Impact (2015). The World Travel and Tourism Council (WTTC), Harlequin Building, 65 Southwark Street, London. 